\title{
Article
}

\section{Assessing the sustainable development goals from a human rights perspective}

Pogge, Thomas $\mathrm{W}$ and Sengupta, M

Available at http://clok.uclan.ac.uk/15557/

Pogge, Thomas $W$ and Sengupta, M (2016) Assessing the sustainable development goals from a human rights perspective. Journal of International and Comparative Social Policy . pp. 83-97. ISSN 2169-9763

It is advisable to refer to the publisher's version if you intend to cite from the work. http://dx.doi.org/10.1080/21699763.2016.1198268

For more information about UCLan's research in this area go to http://www.uclan.ac.uk/researchgroups/ and search for < name of research Group>.

For information about Research generally at UCLan please go to http://www.uclan.ac.uk/research/

All outputs in CLoK are protected by Intellectual Property Rights law, including Copyright law. Copyright, IPR and Moral Rights for the works on this site are retained by the individual authors and/or other copyright owners. Terms and conditions for use of this material are defined in the policies page.

\section{CLoK}

Central Lancashire online Knowledge www.clok.uclan.ac.uk

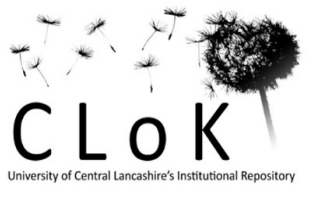




\title{
Assessing the Sustainable Development Goals from a Human Rights Perspective
}

\author{
Thomas Pogge and Mitu Sengupta
}

Transforming Our World: The 2030 Agenda for Sustainable Development (hereon 2030 Agenda) is an intergovernmental agreement meant to guide global development efforts over the next 15 years: from 2016 until 2030. Adopted by the United Nations General Assembly (UNGA) on September 25, 2015, its centerpiece, the Sustainable Development Goals (SDGs), replaces the Millennium Development Goals (MDGs), which held sway from 2000 until 2015. The SDGs are designed to build on the MDGs and "complete what they did not achieve" (2030 Agenda, p. 9).

Like their predecessors, the SDGs are a statement of aspirations: a voluntary agreement rather than a binding treaty. While this presents a drawback insofar as states may be more tempted to skirt their commitments, it also presents an opportunity insofar as states may be willing to adopt a more ambitious agenda when this agenda imposes on them no legally binding obligations. Voluntary intergovernmental agreements, like 2030 Agenda, thus contain the potential to raise the gaze of political elites beyond their usual preoccupations with narrowly defined national interest to think imaginatively about that future cosmopolis whose foundations are now being shaped in this early stage of globalization.

The governments that have signed onto 2030 Agenda certainly exude confidence about the impending positive impact of their "historic decision" (2030 Agenda, p. 6), especially in relation to realizing human rights. The commitment to human rights is expressed already in the preamble (2030 Agenda, p. 9) and is then reinforced by several assurances to the effect that the new text is "grounded in" the Universal Declaration of Human Rights, in international human rights treaties, and in "other instruments such as the Declaration on the Right to Development" (2030 Agenda, p. 8). The document proclaims that the SDGs represent a "supremely ambitious and transformative vision" (2030 Agenda, p. 7), "balance the three dimensions of sustainable development: the economic, social and environmental" (2030 Agenda, p. 7) and "seek to realize the human rights of all" (2030 Agenda, p. 5).

In our judgment, however, the SDGs do not measure up to these fine words and, through this failure, miss an important and, indeed, historic opportunity to articulate our present moral responsibilities along with a truly ambitious and transformative vision of how the world could be, given the knowledge and resources available today. Based on a textual analysis of the new goals and targets, we argue that, despite some clear positives, the SDGs are unlikely to fulfill their self-proclaimed purpose of inspiring and guiding a concerted international effort to realize the human rights of all.

I. The SDGs promote a false sense of success and make it easy for governments to go slow on the realization of human rights

A first and most fundamental concern is the deep tension between presenting moral ambitions in the language of (human) rights and presenting them in the language of (development) goals. The development goals discourse invites an incremental approach to overcoming deprivations: we have a certain distance to traverse, and so we set off toward our destination and approach it step- 
by-step. The human rights discourse, by contrast, suggests that deprivations must be ended right away. When severe deprivations constitute unfulfilled human rights - and, given their social origins, even human rights violations - then they categorically require immediate and toppriority remedial attention. We must spare no effort to realize human rights as fast and fully as we can. When this "we" is the world's national governments united by a common purpose, with their present economic, technological and administrative capabilities, then little can stand in their way toward immediate full realization.

To be sure, the language of goals could be fitted into this picture: our governments could commit themselves to the immediate full realization of all human rights everywhere and call this their goal. But this is not the way the goals language has come to be used in the international development discourse. We see this, for instance, in the MDGs, the first of which envisioned merely halving, over a long 25-year period (1990-2015), the proportion of people in the developing world who live in extreme poverty and the proportion of people who suffer form hunger. Taking population growth into account, this goal in fact envisioned a $27 \%$ reduction in the numbers of people suffering undernourishment and extreme poverty - a mere $1 \%$ reduction each year. Although the UN proudly proclaimed that "the MDGs helped to lift more than one billion people out of extreme poverty," the glacial progress over that quarter century reflects no such effort. The period's ordinary $2.5 \%$ real annual growth in global per capita income, ${ }^{1}$ amounting to a cumulative real (inflation-adjusted) income rise of $85 \%$ over the quarter century, was easily sufficient to achieve the desired modest reductions in undernourishment and hunger. In fact, these reductions would have been much larger if the income gains had not been so heavily concentrated at the very top of the global income distribution.

We could plausibly credit governments with having made an effort only if they had managed to reduce inequality within their respective countries, thereby ensuring that the poorer percentiles of the national income distribution achieved income gains exceeding those from ordinary economic growth. But very few governments reduced domestic inequality in the MDG period. ${ }^{2}$ In most countries, income and wealth inequalities have increased; with the result that the world's poor lost out on some of the gains they would otherwise have reaped from ordinary economic growth. In this way, governments have, if anything, added to the present poverty count by diminishing the impact of ordinary economic growth on poverty reduction. ${ }^{3}$

In any case, it is indisputable that, to put it mildly, governments have failed to "spare no effort" to reduce severe deprivations during the MDG period. They have directed so little of this period's economic growth to the poor that, for example, the number of chronically undernourished people worldwide has fallen by merely $21 \%$ (from 1010.6 to 794.6 million) over those 25 years (FAO, IFAD, \& WFP 2015, p. 8). And even this puny reduction appeared only after the UN Food and Agriculture Organization (FAO) in 2012 implemented, with ample hindsight, a last-minute revision of its methodology, thereby dramatically increasing the official number of undernourished in the 1990s and dramatically decreasing the official number of undernourished in the years after $2008 .^{4}$

This official go-slow approach in regard to overcoming severe deprivations is paradigmatically captured in the expression "progressive realization." In UN-speak, this expression means that (i) we must aim for the full eradication of these deprivations, that (ii) we ought to approach this objective in a continuous manner (without backsliding), and that (iii) we may take as much time as we deem reasonable to complete the task. In these ways, "progressive realization" fulfills the same function as the notorious phrase "with all deliberate speed" in 
Brown v. Board of Education, which in effect allowed Southern states of the U.S. to implement at whatever speed they judged reasonable the admission of black pupils into public schools. ${ }^{5}$

If the happy ending required by progressive realization (first condition) is the full realization of all human rights everywhere, then what is there to criticize? The human rights critique focuses on the avoidable toll of premature deaths and severe deprivations in the extended period during which the goal is being gradually realized. During the MDG period, some 450 million people have died prematurely from poverty-related causes, seven times more than were killed in World War 2. ${ }^{6}$ Our governments could have avoided most of these deaths and could have ended the deprivations. They chose not to. Even today, half of all human beings lack secure access to the objects of their social and economic human rights, and millions die each year as a direct or indirect consequence of such deprivations. And according to our governments' plan, many more years will go by before they will finally bring these massive deprivations and annual poverty death tolls to an end.

The discourse of development goals draws our attention to diachronic comparisons with historical benchmarks: we look at the trend since 1990 or 1960 or 1830, and we invariably find evidence that things have become better than they had been earlier. The language of human rights draws our attention to synchronic comparisons with what would now be possible and, if we cared to make such comparisons, we would invariably find that the extent of present deprivations is far greater than would be unavoidable. It is not surprising, then, that our national politicians and international officials, Western media and the world's affluent people prefer the former mode of presentation. But it does not fit with the language of rights. It does not fit with the recognition that all human beings have human rights to a life in dignity, a life in which they can meet their basic needs.

The former mode of presentation suggests, falsely, that present severe deprivations can somehow be rendered morally acceptable, or more acceptable, by the fact that like deprivations had been even more widespread and severe in the past - or by the fact that, in some future period, such deprivations will have disappeared. To appreciate this monumental moral error, consider the example of slavery in the U.S. ante-bellum South. Imagine a defender of slavery in 1845 describing all the ways in which slavery had become less cruel during the preceding 25 years: slaves were not worked as hard as had been customary in 1820, floggings and rapes of slaves had become less brutal and less frequent, and it had also become less common for slave families to be split apart through sales to different buyers. Would all this progress - and progress it surely is - justify or excuse, in any way, the continuation of the practice of slavery? Evidently, it would not. The fact that slavery had been even worse in earlier times is morally irrelevant. And equally irrelevant is the fact that one could anticipate a time when slavery would be no more. The morally crucial fact is that slavery was, in 1845, a severe and avoidable human rights violation. The government and citizens of the United States were morally required to abolish it right then.

We should make the analogous response to the persistence of widespread undernourishment and other severe poverty-related deprivations: insofar as they are now avoidable, their perpetuation is a grave injustice and they ought to be eradicated from our world as quickly and thoroughly as is humanly possible. Neither the fact that hunger and poverty were even worse in earlier times, nor the anticipated fact that undernourishment and poverty will one day be eradicated, must be allowed to detract from this moral imperative. In both cases, slavery and severe poverty, the morally relevant comparison is not the diachronic one with an earlier state of the world, but the synchronic one with what is presently possible. The abolition of 
slavery was possible in 1845 , and so it should have been abolished then. The worldwide eradication of severe poverty is possible today, so we must eradicate it now, as fast and as thoroughly as we possibly can.

With the synchronic comparison firmly in view, we can apply a different kind of historical comparison. We can ask how much of the severe deprivations extant in different periods of human history were humanly avoidable at those times. Unlike the historical comparison that the development goals discourse encourages, this historical comparison comes out firmly against our present generation. Never in human history has severe poverty been so easily and completely eradicable as in the present period. That we continue to perpetuate it through national and supranational institutional arrangements that are massively skewed in favor of the rich manifests a great moral failing of our generation, of governments and citizens alike.

For many decades now humanity has had the capacity to eradicate undernourishment and other severe deprivations. Yet poverty-related causes still account for about a third of all human deaths, ${ }^{7}$ and severe deprivations are still blighting the lives of humanity's poorest third, whose share of global household income amounts to barely 2 percent. ${ }^{8}$ In human terms, this is a disaster of unimaginable magnitude. In economic terms, it is a manageable challenge comparable to the U.S. invasion of Iraq. ${ }^{9}$

Our response to the disastrous conditions that so many of our contemporaries are subjected to has been morally absurd: we agree that the prevalence of undernourishment and other severe deprivations should gradually shrink, we hope that this will happen through trickle down from economic growth and we resort to creative accounting when increases in income inequality shrink the expected progress. The morally required response is to recognize these deprivations as massive human rights violations that we must stop, at once, by implementing institutional reforms at the national and especially the supranational level to achieve a more equitable distribution of income and wealth, ensuring that even the poorest can meet their basic needs (see further subsection III.3 below).

To sum up our first point. The development goals discourse invites a diachronic, incremental approach: we gradually reduce severe deprivations over several decades. The human rights discourse, by contrast, brooks no such delay. Once we recognize a human right not to be enslaved, we must not make a 25-year plan aiming to halve the number of slaves or aiming to reduce floggings by half. Once we recognize a human right not to be exterminated, we must not make a 25-year plan to halve the killing rate at Nazi concentration camps. Once we recognize a human right not to be subjected to economic institutions under which hundreds of millions foreseeably and avoidably cannot meet their basic needs, we must not make a 25 -year plan to reduce these severe deprivations by $27 \%$ but must initiate the necessary institutional reforms right away. And our governments have, of course, recognized and reiterated such a human right many times - not merely fleetingly, as in the 2030 Agenda, but also carefully and systematically in the official human rights documents such as, most prominently perhaps, the International Covenant on Social, Economic and Cultural Rights which, adopted in 1966 and legally binding since 1976, postulates "the fundamental right of everyone to be free from hunger" and other severe poverty-related deprivations. ${ }^{10}$

Conversely, if we do regard the eradication of undernourishment and other severe deprivations as a goal to be slowly approached over several lengthy development goal cycles, thereby accepting hundreds of millions of poverty-related deaths and deprivations in the interim, then we are in effect denying that there is a human right to life, a human right to an adequate standard of living, a human right to be free of hunger. 


\section{The SDGs fail to specify what a human-rights-based duty or genuine goal to eradicate severe poverty requires: a clear division of labor}

In a way, the world's response to persistent severe deprivations has been even worse than outlined insofar as we have not even really satisfied the demands of the goals language. The concept of a goal implies some definite individual or collective agent whose goal it is. And it implies that this agent has a reasonably clear idea about the steps it will take to achieve the goal and also has both the commitment and the means necessary to take these steps. Many people before John F. Kennedy had expressed the desire that human beings should visit the moon. But for them such a visit was not a goal because they either had no idea how to get there or else lacked the necessary means for organizing such a journey. They were not aiming at, but rather wishing for, such a visit. Kennedy, however, transformed this wish into a goal. Unable to bring about such a voyage single-handedly, he needed to conceive a plan for collective action and to assemble a coalition of agents (legislators, scientists, engineers, corporate leaders, etc.) all willing and able to do their part. This facilitation of an organized collaboration, involving a division of tasks and responsibilities, transformed a widely shared wish into a common goal.

This is not to say that common goals presuppose a single leader. A group can decide collectively what to aim for and how to get there. But, to have a common goal, this group must have a shared understanding of who is to do what toward implementation. As no such shared understanding emerged around the MDGs, it would be more appropriate to refer to them as the Millennium Development Wishes. Governments publicly agreed that it would be a good thing if a certain set of propositions were to come true by 2015. Let the prevalence of hunger be half of what it was in 1990 and let the prevalence of under-5 mortality go down by two thirds! But governments never agreed on a division of labour toward making these propositions true. The agreement left entirely unspecified who was to do what. So, when we fell behind, badly, on the undernourishment and child mortality targets, there was no authoritative way of identifying the party or parties required to make additional efforts to get us back on track. This complete exclusion of specific responsibilities from the agreement made it easy for governments to sign on, because they were committing themselves to nothing in particular: should some of the agreed wishes remain unfulfilled, each government could always respond by lamenting others' insufficient exertions. And so it indeed happened when progress stalled: governments looked encouragingly at one another with the sharable prompt that "somebody ought to do something!"11

Now in this game of blame shifting, the developed West has the advantage of possessing the loudest and savviest media. If no division of labor is specified for achieving the SDGs, there is a real danger, then, that any failures will be blamed on the poorest countries. This is exactly what happened during the MDG era, when Western media propagated the notion that each country is in charge of achieving the MDGs within its own jurisdiction: if we are to reduce by two thirds the global rate of children dying before the age of 5 , then each country should reduce its under-5 mortality rate by two thirds. If the world is underperforming, then the fault lies with the governments of the underperforming countries.

But such a division of labor is evidently hugely unfair, because it saddles the poorest, least capable countries with the largest responsibilities: the poorer and hence less capable a country is, the larger is its task. Extremely poor countries with very high birth rates, such as Angola, Burkina Faso, Chad, East Timor, Ethiopia, Guinea, Liberia, Malawi, Mali, 
Mozambique, Niger, Nigeria, Sierra Leone, Somalia, Uganda and Zambia were supposed to get their under-5 mortality rates down from around 200 (per 1000 children born) to 70 or so, while rich countries like Japan and the U.S. needed to reduce their rates only from 6 to 2 or from 11 to 4 , respectively. ${ }^{12}$ So the rich countries and their media suggested that the poorest, least capable countries should take on the largest shares of the global task and the richest countries disproportionately tiny shares. This is an extremely unfair division of labor, made even more unbalanced by the fact that the "developed regions" were even excluded entirely from some of the MDGs (e.g., from the first MDG featuring the undernourishment and extreme-poverty targets). It is also an ineffective division of responsibilities because, with their 100 times smaller per capita government budgets, the poorest countries cannot fund the necessary work on their own - certainly not so long as the affluent states operate an international fiscal and financial regime that makes it easy for multinational corporations and wealthy individuals to dodge their taxes in poor countries with the help of tax havens, secrecy jurisdictions, letterbox companies, sham trusts and plenty of corrupt bankers, accountants, lawyers and financial advisers (Pogge and Mehta 2016). Nonetheless, given that the MDGs specified no division of labor, it was easy for Western officials and media to propagate this lopsided and unproductive allocation of responsibilities, which the developing countries, of course, never accepted.

In contrast to the MDGs, many if not most SDGs are worded to be applicable to all countries, rich and poor alike. Some targets, such as that to "reduce by one third premature mortality from non-communicable diseases through prevention and treatment and promote mental health and well-being" (2030 Agenda, p. 20), are of ringing relevance to developed countries. Moreover, unlike the MDGs, which called for reductions in a few central dimensions of poverty, the SDGs proclaim the far bolder commitment to "end poverty in all its forms everywhere" (2030 Agenda, p. 18). This is a genuine improvement, not only because it recognizes that human rights deficits, such as severe poverty, hunger, torture and discrimination, are morally unacceptable, but also because getting to zero requires an honest focus on empowering the poorest and hardest to reach, even in the most affluent countries of the world. While goals and targets such as to "end poverty in all its forms everywhere" (ibid.), to "end all forms of discrimination against all women and girls everywhere" (2030 Agenda, p. 22) and to "end abuse, exploitation, trafficking and all forms of violence against and torture of children" (2030 Agenda, p. 30) are meaningful to the poorest countries on the planet, they are also relevant to its wealthiest states. So are the goals and targets committed to attaining universal provision or access in areas such as healthcare, education, and financial services. After all, uneven healthcare coverage and violence against children are as much reasons for action in the United States and Europe as they are in far less affluent countries of the world.

From a human-rights perspective, the SDGs are thus an improvement over the MDGs in that they more frequently envision full (albeit slow) eradication rather than reduction and are committed to an agenda that is universal in scope. This clear positive is offset, however, by the fact that important goals are not framed in universal terms, but in terms of what is "nationally appropriate." For example, under the goal "end poverty in all its forms everywhere" (2030 Agenda, p. 19), there is no commitment to a collectively maintained universal social protection floor, but merely the call for "nationally appropriate social protection systems and measures for all, including floors" (2030 Agenda, p. 19).

It is understandable - especially after unfairly excessive expectations had been imposed upon the poorest countries in the MDG period - that 2030 Agenda falls far short of adopting a universal zero target approach for all economic and social human rights obligations. During the 
preceding intergovernmental consultation sessions, developing countries, led by the Group of 77 (G77) and China, referenced the principle of common but differentiated responsibilities and argued that, while the SDGs should be made relevant to all countries, the roles and responsibilities in the implementation of the goals should be differentiated according to the different national realities, capacities and levels of development of different countries and also according to national policies and priorities (Muchala 2014). This demand, which led to the inclusion of nationally determinable targets and language on respecting national policy space, ${ }^{13}$ reflects a legitimate concern that bold, zero goals would be used to shame and blame developing countries that simply lack the capacity to achieve them.

The solution, however, should not have been to dilute the SDGs by aiming for whatever is feasible with national resources. Instead, the SDGs should have specified the responsibilities of wealthy countries and enterprises in relation to these goals, identifying what they must do to reduce impediments and to increase assistance, so that ambitious targets can be met even in the poorest countries. Doing so, in fact, would have been in line with 2030 Agenda's stated commitment to realizing the right to development ${ }^{14}$ and the internationalization of responsibility this right entails.

This brings us to a more general analysis of the new global partnership goal, SDG 17, which was intended to be a more ambitious version of the paltry MDG 8, but ended up suffering from the same key defect. The world's most powerful agents - affluent states, international organizations, multinational enterprises - are once again shielded from any concrete responsibilities for achieving the SDGs. Given their wealth and influence, they ought to be taking the lead in providing the needed resources - for example, for meeting the enormous challenge of improving the data collection capacities of developing countries - and in implementing systemic institutional reforms that will address the root causes of poverty. These needed reforms include changing the rules that encourage illicit financial outflows from developing countries or force the poorest countries to repay, with interest, the debts accumulated by their previous unauthorized, illegitimate and unaccountable rulers. The targets for SDG 17 should have specified the concrete responsibilities of the affluent states in regard to implementing needed global institutional reforms and financing sustainable development. ${ }^{15}$ If the world's most influential agents had been held sufficiently accountable for what they owe toward making sustainable development work, the concepts of partnership and universalism would have been more meaningful, rather than what they are now likely to become: a smokescreen for extreme global inequalities.

Work is now being done on clarifying the "means of implementation" for the SDGs. This work is crucial for transforming a list of shared wishes into a list of common goals. To achieve such a transformation, this work must develop a clear and mutually agreed division of tasks and responsibilities. It is not enough to specify, however precisely, what needs to be done; governments must also agree, for each specific task, who is responsible for ensuring that it actually gets done. If no such division of labor is agreed upon, then all we have is a long list of Sustainable Development Wishes along with the pious hope that economic growth and charitable activities will move things far enough in the right direction.

Needless to say, resting content with such pretty wishes and pious hopes would exacerbate our failure to meet the stringent responsibilities implied by human rights language. Not only are we deferring the realization of human rights far into the future, thereby severely disrespecting all those people who are now in jeopardy and thus unlikely ever to survive to that promised land of 2030 - but we are even failing to take minimally necessary steps to ensure that 
this promised land will even be there: that the huge present human-rights deficit will really, by 2030, shrink as much as hoped for.

\section{The full realization of human rights requires a massive roll-back of international and intra-national inequalities, which the SDGs fail to demand}

The commitment to the full realization of human rights entails a commitment to curtail economic inequalities, and this for three distinct reasons: mathematical, intrinsic, and political.

III.1 The first reason arises from the mathematical fact that the absolute position of any poor persons or groups is fully determined by their relative position (the extent of national or global inequality) and by the national or global average. To make the point in the simplest way, focused on money: when (as is approximately true) the poorest quarter of the human population get $1.2 \%$ of global income ${ }^{16}$ and the global average annual income is $\$ 10,000$, then the income among the poorest quarter of humanity is approximately $\$ 480$ per person per year. Insofar as more is required for the realization of human rights, we must work to increase either the global average income or the global income share of the poorest quarter.

The international development discourse is heavily focused on the first factor, on global economic growth conceived as a rising tide that lifts all boats. But there are two problems with this focus on growth. First, whereas human rights require immediate realization, insofar as this is reasonably possible, growth takes lots of time. Forward-going, we can count on no more than $1.2 \%$ real annual growth in the global average income; and at this rate it takes fully 58 years for incomes to double. ${ }^{17}$ Given the enormous hardships that poverty undeniably causes in terms of disease, hunger, homelessness, illiteracy, oppression, dependency, disease and premature deaths, ${ }^{18}$ such a glacial pace of poverty eradication is morally intolerable. Doubling the incomes of the global poor can be achieved much faster if we reduce national and global inequality. We can then aim to bring the global income share of the poorest quarter from $1.2 \%$ up to $2.4 \%-$ something that can be achieved much faster and, by the way, could evidently be done with only trivial impact on the other income shares.

Second, growth has limits and itself poses threats to the realization of human rights. This becomes clearer when we look beyond income, at land use for example or at energy consumption. To be adequately nourished, the poor need more food and this in turn requires that more land - say 30 percent more - be devoted to meeting their needs. Relying on growth alone, and thus holding inequality constant, we would let global land cultivation increase by $30 \%$, which would have large ecological costs for all of humankind. Overcoming the deficit through a decrease in the inequality of land use, by contrast, would enable us to eradicate the nutritional deficits of the poor while increasing aggregate human land use only marginally or not at all. Similarly, for energy, in order to meet their basic needs, the world's poor may need to double their current energy consumption. But this does not require us to plan - and wait for - a doubling of global energy output: by allowing inequality to decline, we can allow the poor to meet their energy needs without doubling global power generation. If the poor have a larger share of global income, they can use it to obtain a larger share of global energy production - and can ensure that a larger share of cultivated land is devoted to meeting their nutritional needs, rather than to golf courses and prime beef production.

III.2 Coming now to the intrinsic link between human rights and inequality, in some cases human rights prescribe equality, as in access to the law, education, gender equality, and so on. In regard to the SDGs, it is a clear positive that the principles of equality and nondiscrimination have received explicit recognition. Moreover, in keeping with the principle of 
"leave no one behind," which was widely endorsed in global consultations on the post-2015 agenda, the SDGs commendably contain a commitment to considering targets achieved only if they are met for all segments of a population, especially those who might be subject to discrimination on grounds prohibited in international human rights law. This is articulated in the pledge to disaggregate relevant data "by income, gender, age, race, ethnicity, migratory status, disability, geographic location and other characteristics relevant in national contexts" (2030 Agenda, p. 32).

There is reason, however, to remain skeptical of the SDGs' commitment to reducing inequality and ending discrimination. First, the concern to avoid inequality is not integrated into other goals in a crosscutting manner, as it should have been. This was done for the objectives of combating climate change and achieving gender equality: both were addressed through standalone goals (SDG 13 and SDG 5), as well as targets woven through other goals, such as SDG 4.8 , which seeks to eliminate gender disparities in education. In contrast, there is no explicit reference to reducing inequality within and among countries outside of SDG 10.

Second, the list of grounds for potential discrimination recognized by the SDGs is not complete. Given the otherwise progressive tenor of SDG 5 and its associated targets - and the attempt to recognize gender equality as a multidimensional concept - it is a glaring omission that there is no language whatsoever on ending discrimination, violence, and denials of sexual and reproductive rights on the basis of a person's sexual orientation, gender identity, or gender expression. Ending such gender-based discrimination should be recognized as a core human rights imperative crucial to achieving sustainable development. Because of their real or perceived sexual orientation, gender identity or gender expression, many people are not only bullied, beaten, raped, and murdered, they are marginalized, isolated and denied access to education, employment, healthcare, housing, social assistance and community resources. Sadly, even in 2016, ending discrimination on the basis of sexual orientation and gender identity remains a politically sensitive issue. If we are serious about attaining sustainable development for all human beings, about leaving no one behind and about raising the gaze of the world through the SDGs, then this issue should not have been negotiable.

Finally, it is difficult to take the SDGs' promise to end discrimination seriously when there is no explicit reference, in their text, to a number of key civil and political rights - such as freedom from arbitrary arrest and detention, the freedoms of thought, expression, and association, and the rights of ethnic minorities - that empower people who suffer discrimination to realize a host of other rights.

III.3 Proceeding to the political link between human rights and inequality, the distribution of future economic gains, and the future distribution of social and economic advantages more generally, is heavily influenced by the design of national and international social and economic rules and practices. Because this is well known, the formulation of such rules and practices is heavily contested by various interested parties, such as industry associations, corporations, banks, hedge funds, unions and NGOs, all of whom expend substantial efforts on lobbying for rules that are favorable to themselves or their constituents. Such lobbying requires resources (money, information, relationships), and the capacity for successful lobbying is roughly proportional to the resources agents can bring to bear. Those who are relatively poor tend to be politically marginalized, even in democratic societies. As a result, their needs, interests and voices typically have little impact on the formulation of rules and policies with the result that their share of wealth and income shrinks even further and they fall farther and farther behind in health, education and social recognition. ${ }^{19}$ 
Wealthy people and their associations - corporations, banks, hedge funds, foundations and lobbying firms - have enormous advantages in scale, information, expertise and political influence. This enables them to do better than others under the existing rules. It also enables them to influence the formulation and application of these rules to their own advantage, thereby further increasing the shares of wealth and income they capture. In the absence of compensatory mechanisms, such as inheritance and progressive income taxes, the rules of a national economy will increasingly reflect the interests of the more affluent citizens and generate a tendency toward greater inequality.

This danger is especially serious at the supranational level where the vast majority of the human population is unable to exert any meaningful political influence on the rules of the game. Intergovernmental negotiations are typically conducted in secret, with government negotiators talking to their most powerful constituents but not to the media or the general public. It is difficult for voters to hold their government responsible for a negotiated agreement because many other governments were also involved in its formulation. And moral concerns are easily dismissed as naïve in the context of the jungle of international relations where each state must supposedly prioritize its own power and survival. It is unsurprising, then, that the recent globalization period - characterized as it is by a massive shift of governance from the national to the supranational level - has primarily benefited the most advantaged constituents of the most powerful states, especially the economic elite of the U.S., whose government is the most powerful and (among the industrialized countries) the most easily bought. ${ }^{20}$ As international rules and policies gain in influence and increasingly reflect the interests of global elites, economic inequalities mount and the human rights, needs, interests and voices of the poor are increasingly marginalized and easily disregarded - both within countries and also in the ever more important arena of supranational institutional design.

III. 4 Given these three important reasons, it was crucially important to include in the 2030 Agenda a stand-alone goal to reduce inequality. Despite forceful efforts to cut this goal from the final draft, or at least to submerge it as a mere target under some other goal (such as poverty eradication or economic growth), the stand-alone goal was successfully defended: "reduce inequality within and among countries" (2030 Agenda, p. 25).

Unfortunately, the first target within this goal, which should have specified how this was to be achieved, instead badly undermines this goal when it asks that governments "by 2030, progressively achieve and sustain income growth of the bottom 40 per cent of the population at a rate higher than the national average" (2030 Agenda, p. 25). By asking that such faster income growth for the poorest $40 \%$ should be achieved (and then sustained) sometime before 2030, this target effectively permits countries to continue to shrink the income share of the poorest $40 \%$ for another 13 years. SDG 10.1 is compatible, then, with a dramatic increase in inequality over the whole 2016-30 period. What we urgently need is the opposite: a roll-back of national and global inequality so that the income-share of the poorest $40 \%$ will be substantially higher at the end of the period than at its beginning.

A suitable specification of SDG 10 would be the commitment to halve, by 2030, each country's logarithmic distance from a Palma ratio of 1 . The Palma ratio is the total income of the $10 \%$ with the highest incomes divided by the total income of the $40 \%$ with the lowest incomes. ${ }^{21}$ Halving the logarithmic distance means that, between now and 2030, each country moves from its present Palma ratio to the square root of its present Palma ratio. This would mean that countries with current Palma ratios of 4, 2.25 and 1.69 would commit to reaching, by 2030, 
Palma ratios of 2, 1.5 and 1.3 , respectively. ${ }^{22}$ Countries with current Palma ratios of 1 or below would merely need to remain within this range. ${ }^{23}$

Finally, SDG 10 does not sufficiently recognize the need to design economic rules both national and global - that will keep inequality within certain bounds. For example, there is no reference in the "means of implementation" for SDG 10 to the need for inheritance and progressive income taxes, nor to any measures designed to reduce international inequalities. Given that the distribution of future growth is heavily influenced by the design of national and international economic rules and practices, the absence of any language on reforming such rules is unfortunate indeed. In fact, overall, the SDGs contain only a few passing references to institutional reforms that could diminish the headwinds blowing against the poor, although such reforms are crucial for the achievement of every goal.

\section{IV. $\quad$ Concluding Remarks}

Our focus in this article is on three important points. There is, first, the deep tension between presenting moral ambitions in the language of (human) rights and presenting them in the language of (development) goals. The discourse of development goals draws our attention to diachronic comparisons with historical benchmarks: we look at the trend and invariably find that things have become better than they had been before. Such comparisons, however, are wholly out of place when rights are at issue. The language of human rights draws our attention to synchronic comparisons with what would now be possible, given the available knowledge and resources. If we cared to make such comparisons, we would invariably find that the extent of present deprivations is far greater than would be unavoidable, and we would not be tempted to praise as "supremely ambitious and transformative" (2030 Agenda, p. 7) a plan to reduce these deprivations some more over the next 15 years.

Our second point is to argue that the SDGs do not even really satisfy the demands of the goals language. The concept of a goal implies some definite individual or collective agent whose goal it is. It implies, furthermore, that this agent has a reasonably clear idea about the steps it will take to achieve the goal and also has both the commitment and the means necessary to take these steps. We showed how the SDGs fail in this regard by shielding the world's most powerful agents from any concrete responsibilities for achieving the new goals, when, given their wealth and influence, they ought to be taking the lead in providing the needed resources for sustainable development and in implementing systemic institutional reforms that address the root causes of poverty. The assembled governments wish that the human rights of the poor will be realized, but they have no plan for contributing to this realization, thus effectively entrusting this task to the vagaries of charity and economic growth.

Our third and related point highlights the SDG's tepid commitment to tackling discrimination and inequality. If the human rights of the world's poor are to be realized in the foreseeable future and if the poor are to be able to defend their rights and interests in the arenas of politics and public opinion, then they must not continue to be reduced to a tiny sliver of the global average income. And reducing inequality is important also in the affluent countries, where the combination of increasing economic inequality and a range of powerful new technologies poses a mortal threat to the survival of democracy. By postponing the rollback of inequality to 2029, as SDG 10.1 is suggesting, we are courting a relapse into a dark age of oppression and domination.

In this article we were able only briefly to allude to three other respects in which the new SDGs fall short when examined from a human rights perspective. First, despite omnipresent 
official protestations to the effect that human rights are indivisible, interdependent and interrelated, the SDGs cover only a subset of the internationally recognized human rights that remain widely unrealized among the poor. Second, the SDGs fail to reflect on the root causes of the huge and persistent poverty-related human rights deficit and they consequently ignore the structural reforms we urgently need to make national and supranational institutional arrangements less skewed toward the interests of a tiny global power elite. ${ }^{24}$ Third, the SDGs fail to envision the kind of independent monitoring without which we cannot reliably assess the magnitude, geographical and demographic distribution and trend of human-rights-relevant deprivations. Allowing this monitoring to be monopolized by politically exposed and vulnerable intergovernmental agencies (such as the World Bank and the FAO), whose chiefs are appointed and whose funds are dependent on governments, puts these agencies in an impossible position and predictably involves them in cosmetic efforts toward giving the politicians the trend figures they want. $^{25}$ 


\section{Bibliography}

Brown v. Board of Education, 347 U.S. 483 (1954).

Cingano, F. (2014). Trends in Income Inequality and its Impact on Economic Growth (Working Paper No. 163). Paris: Organisation for Economic Co-operation and Development. Retrieved from http://www.oecd-ilibrary.org/content/workingpaper/5jxrjncwxv6j-en

Cobham, A., \& Sumner, A. (2013a). Is it All About the Tails? The Palma Measure of Income Inequality. (Working Paper 343). Center for Global Development. Retrieved from http://www.cgdev.org/sites/default/files/it-all-about-tails-palma-measure-incomeinequality_edit.pdf

Cobham, A., \& Sumner, A. (2013b). Putting the Gini Back in The Bottle? The Palma As a Policy-Relevant Measure of Inequality. Unpublished. Retrieved from http://www.kcl.ac.uk/sspp/sga/idi/people/Sumner/Cobham-Sumner-15March2013.pdf

Deacon, B. (2016)....

FAO, IFAD, \& WFP. (2015). State of Food Insecurity in the World. Paris: Food and Agriculture Organization. Retrieved from http://www.fao.org/3/a-i4646e.pdf

GeoHive (2013) Population of the Entire World Yearly [Dataset]. Retrieved January 23, 2016, from http://www.geohive.com/earth/his_history3.aspx.

Louise, J., Fyson, C., Alexander, R., Gutschow, J., Rocha, M., Cantzler, J., Blok, K. (2015). 2.8 Degrees Celsius is Not Enough-We Can Get Lower(Briefing). Climate Action Tracker.

Manyika, J., Woetzel, J., Dobbs, R., Remes, J., Labaye, E., \& Jordan, A. (2015). Can long-term global growth be saved?|McKinsey \& Company. New York: McKinsey \& Company. Retrieved from http://www.mckinsey.com/global-themes/employment-and-growth/canlong-term-global-growth-be-saved

Muchhala, B. (2014, March 14). North-South Debate in the UN with Context of Sustainable Development Goals. Retrieved from http://www.twn.my/title2/unsd/2014/unsd140303.htm

NASA (2016) GIS Surface Temperature Analysis. Retrieved from http://data.giss.nasa.gov/gistemp/graphs_v3/

Piketty, T., \& Saez, E. (2003). Income Inequality in the United States, 1913-1998. The Quarterly Journal of Economics, 118(1), 1-41. http://doi.org/10.1162/00335530360535135

Pogge, T. (2010). Politics as Usual: What Lies Behind the Pro-Poor Rhetoric. Cambridge, UK; Malden, MA: Polity.

Pogge, T (2016). "The Hunger Games," in Food Ethics 1(1), 9-27, preprint freely downloadable at http://link.springer.com/article/10.1007/s41055-016-0006-9”. 
Pogge, T., \& Mehta, K., eds. (2016). Global Tax Fairness. Oxford: Oxford University Press.

Pogge, T., \& Sengupta, M. (2014). Rethinking the Post-2015 Development Agenda: Eight Ways to End Poverty Now. Global Justice: Theory Practice Rhetoric, 7, 3-11.

Sachs, J. (2006). The end of poverty: economic possibilities for our time. New York: Penguin Books.

Sengupta, A. (2002). On the Theory and Practice of the Right to Development. Human Rights Quarterly, 24(4), 837-889. http://doi.org/10.1353/hrq.2002.0054

Shah, A. (2013, January 7). Poverty Facts and Stats. Retrieved from http://www.globalissues.org/article/26/poverty-facts-and-stats

Trotta, D. (2013, March 14). Iraq War Costs U.S. More that \$2 Trillion: Study. Reuters. Retrieved from http://www.reuters.com/article/us-iraq-war-anniversaryidUSBRE92D0PG20130314

UN General Assembly (1966). International Covenant on Economic, Social and Cultural Rights, United Nations, Treaty Series, vol. 993, p. 3, available at: http://www.refworld.org/docid/3ae6b36c0.html [accessed 27 February 2016]

UN General Assembly (2015) Transforming Our World: The 2030 Sustainable Development Agenda, $70^{\text {th }}$ Session, UN Doc, A/Res/70/1.

United Nations Development Program. (2007). Human Development Report 2007-2008. New York: Palgrave Macmillan. Retrieved on March 30, 2016, from http://hdr.undp.org/sites/default/files/reports/268/hdr_20072008_en_complete.pdf

UNU-WIDER (2015). World Income Inequality Database (WIID3c)[Dataset]Retrieved January 24, 2016 from, https://www.wider.unu.edu/project/wiid-world-income-inequalitydatabase.

World Bank (2015). World Development Indicators [Dataset] Retrieved on January 24, 2016, from http://data.worldbank.org/indicator/SH.DYN.MORT?page=5.

World Bank (2016). PovCal: An online analysis tool for global poverty monitoring [Dataset] Retrieved on April 3, 2016, from http://iresearch.worldbank.org/PovcalNet/ )

World Health Organization (2008). Global Burden of Disease: 2004 Update. Geneva: World Health Organization Publications. Retrieved from www.who.int/healthinfo/global_burden_disease/2004_report_update/en/index.html 
${ }^{1}$ McKinsey (2015) reports that real growth of the world economy has been 3.8\% in recent decades. To calculate real global economic growth per capita, one must diminish this growth rate by subtracting the rate of global population growth, which, over the MDG period, has averaged about $1.3 \%$ per annum. See www.geohive.com/earth/his_history3.aspx (last visited January 23, 2016).

2 "More than 80 percent of the world's population lives in countries where income differentials are widening" (UNDP 2007, p. 25). See also UNU WIDER 2015.

${ }^{3}$ The World Bank's own data shows that, in 1990, $69.5 \%$ of those living in extreme poverty in the developing world lived close enough to the Bank's international poverty line so that an $85 \%$ income increase would lift them above. See http://iresearch.worldbank.org/PovcalNet/ (last visited April 3, 2016). Thus, had our governments been more ambitious, aiming for a $69.5 \%$ reduction in extreme poverty over the 1990-2015 period, they could have achieved this by merely ensuring that the poor participate proportionately in global economic growth.

${ }^{4}$ Pogge 2016. Another example of such creative accounting is provided by the World Bank's defining poverty ever more narrowly by replacing the original purchasing power parity threshold of $\$ 1.00$ per person per day in 1985 USdollars (as referenced in the UN Millennium Declaration and in MDG 1) with a lower threshold of \$1.08 per person per day in 1993 US-dollars, and then with an even lower threshold of \$1.25 person per day in 2005 US-dollars. This has led to a much prettier poverty trend, as can be seen from the World Bank's own trend numbers for different poverty lines. Defining poverty in terms of daily expenditure with the absurdly low purchasing power of $\$ 1.25$, the Bank calculates that poverty has fallen by $61 \%$ : from $43.45 \%$ of the population of the developing countries in 1990 to $16.99 \%$ in 2011 . Had the Bank used a more reasonable poverty line, reflecting daily purchasing power of $\$ 3.00$, say, then it would find that poverty has fallen by less than $31 \%$ : from $76.29 \%$ in 1990 to $52.80 \%$ in 2011 . For more extensive discussion, see Pogge (2010, pp. 63-68).

${ }^{5}$ Brown v. Board of Education, available at https://supreme.justia.com/cases/federal/us/349/294/case.html (last visited January 23, 2016). See also http://americanhistory.si.edu/brown/history/6-legacy/deliberate-speed.html (last visited January 22, 2016) for some historical background.

${ }^{6}$ This estimate is based on the WHO's classification of deaths by cause, counting as poverty-related all those death causes that are essentially confined to the poor countries. When almost no one dies of diarrhea in the affluent countries and millions die from diarrhea in poor countries, then we can safely assume that diarrhea is a povertyrelated cause and diarrhea deaths are poverty-related. We have used the WHO's data for 2004 (World Health Organization 2008), summing to 18 million deaths, because this year is roughly in the middle of the MDG period. Now, to be sure, other causes of death - cancer, cardiovascular disease, diabetes, accidents - may also discriminate against the poor, killing them prematurely where their more affluent peers would have survived longer. We have not counted any of these deaths as poverty-related, and our estimate is in this respect a conservative one.

${ }^{7}$ See note 6 above.

${ }^{8}$ At current exchange rates, as estimated by Branko Milanovic and communicated by email on December 24, 2014.

9 "The U.S. war in Iraq has cost $\$ 1.7$ trillion with an additional $\$ 490$ billion in benefits owed to war veterans, expenses that could grow to more than $\$ 6$ trillion over the next four decades counting interest, a study released on Thursday said" (Trotta 2013). The cost of eradicating extreme poverty worldwide is estimated at $\$ 3.5$ trillion (Sachs 2006, envisioning a concerted effort over 20 years).

${ }^{10}$ Article 11(2) of the International Covenant on Social, Economic and Cultural Rights (UN General Assembly 1966).

${ }^{11}$ The recent Paris climate accord is another perfect example of this strategy of mollifying the public by announcing ambitious wishes. Our governments agreed on a stellar proposition: that human greenhouse gas emissions would not raise the global mean surface temperature by more than 1.5 degrees Celsius above the pre-industrial level (we are now slightly above +1.0 degree, see http://data.giss.nasa.gov/gistemp/graphs_v3/, last visited April 3, 2016). In addition, each government pledged its own Intended Nationally Determined Contribution. If all governments fully 
and successfully implement their pledges, the global average surface temperature will, already by 2100 , rise to exceed the pre-industrial level by about 2.7 degrees Celsius (http://climateactiontracker.org/assets/publications/briefing_papers/CAT_Temp_Update_COP21.pdf, last visited January 25, 2016). Despite this obvious disconnect between their agreed wish and their individual pledges, our governments did manage to inspire widespread celebrations and complacency: phew, this problem is solved!

${ }^{12}$ National under-5 mortality rates for 1990 can be found at http://data.worldbank.org/indicator/SH.DYN.MORT?page=5 (last visited January 24, 2016).

${ }^{13}$ For instance: "respect each country's policy space and leadership to establish and implement policies for poverty eradication and sustainable development" (2030 Agenda, SDG 17.15, p. 32).

${ }^{14}$ See www.un.org/en/events/righttodevelopment/pdf/rtd_at_a_glance.pdf, last visited January 24, 2016. See also Sengupta 2002.

${ }^{15}$ We discuss needed supranational institutional reforms in Pogge and Sengupta 2014. Also add here crossreference to Bob Deacon's piece.

${ }^{16}$ At current exchange rates, as estimated by Branko Milanovic and communicated (to Thomas Pogge) by email on December 24, 2014.

${ }^{17}$ Manyika et al. (2015) provides data on expected future real global economic growth, projecting that real growth will average about $2.1 \%$ per annum over the next 50 years. To calculate real global economic growth per capita, one must diminish this growth rate by subtracting the rate of global population growth, which, over the SDG period, is expected to average about $0.9 \%$ per annum. See www.geohive.com/earth/his_history3.aspx (last visited January 23, 2016).

${ }^{18}$ On the dynamics of inequality and its relationship to education, nutrition, income, gender, and health, and perceptions of inequality, see generally UNITED NATIONS DEVELOPMENT PROGRAMME. On the extent of deprivations worldwide, see GLOBAL ISSUES, Poverty Facts and Stats, http://www.globalissues.org/print/article/26 (last visited Feb. 7, 2015).

${ }^{19}$ The United States during the last 35 years offers a dramatic example of such a self-reinforcing trend toward greater inequality. Here the income share going to the top $1 \%$ of the population has increased from under 9 per cent in the late 1970 s to $21.24 \%$ in 2014. In the same period, the income share going to the top 0.01 per cent has risen even more dramatically from 0.85 to 4.89 per cent. These 31,000 US residents now have nearly half as much income as the poorer half of their compatriots (155 million people) and more income than the poorest 35 per cent of humanity (2.5 billion people). See Emmanuel Saez and Thomas Piketty, "Income Inequality in the United States, 1913-1998," Quarterly Journal of Economics 118 (2003), pp. 1-39. Tables and Figures Updated to 2014 in Excel format, June 2015, data from elsa.berkeley.edu/ saez/, Table A3 (last visited January 24, 2016).

${ }^{20}$ E.g., through weakly regulated contributions to political campaigns and political action committees (PACs and SuperPACs). See note 19 above.

${ }^{21}$ For a detailed discussion of the Palma ratio with empirical data from many countries, see Cobham and Sumner $2013 b$.

${ }^{22}$ Let us illustrate with a hypothetical example. Suppose a country has a Palma ratio of 4, with the richest $10 \%$ of its population capturing $40 \%$ of national household income and the poorest $40 \%$ capturing only $10 \%$. To achieve the envisioned Palma ratio of 2, this country might aim to raise the national income share of the poorest $40 \%$ from $10 \%$ to $17 \%$ while gradually shrinking the income share of the richest $10 \%$ from $40 \%$ to $34 \%$. At the beginning of the SDG period, the average income of the richest $10 \%$ would be 16 times the average income of the poorest $40 \%$. At the end of the SDG period, the average income of the richest $10 \%$ would be 8 times the average income of the poorest $40 \%$. The ideal Palma ratio of 1 is reached when the average income of the richest $10 \%$ is 4 times the average income of the poorest $40 \%$.

${ }^{23}$ For a discussion and defense of the Palma ratio as a fitting measure of inequality, see Cobham and Sumner 2013a. For Palma ratio data from various European countries, see Cingano 2014.

${ }^{24}$ See note 15 above. 
${ }^{25}$ See note 4 above. 